\title{
CONTENTS OF CLINICAL HEMORHEOLOGY, VOLUME 15, NUMBER 4
}

H. Kisewetter, K. Erdlenbruch, J. Koscielny, F. Jung, G. Pindur and E. Wenzel

G. Caimi

Wen Zong-yao, Ma Weiyuan, Gao Tie and Sun Dagong

P. Mercié, M. Seigneur, J. Constans,

P. Dufourcq, M. Longy-Boursier, J.L. Pellegrin, C. Beylot, P. Fialon, A. Pruvost, J. Beylot, M.R. Boisseau and C. Conri

M.V. Kameneva, A.S. Parfenov, L.D. Chirkova and I.P. Baskova

M. Krotkiewski, A. Belboul, S. Palm Z. Brzezinska, B. Liu and D. Roberts

P. Költringer, W. Langsteger and O. Eber

G. Caimi, R. Lo Presti, M. Montana B. Canino, G. Grifò, G. Ventimiglia, A. Romano, A. Catania and A. Sarno
Non-Conference Communications Papers

601 Efficacy of hypervolumetric hemodilution with HES 200/0.5 6\% versus ringer lactate in patients with asystemic vertigo

613 Erythrocyte membrane fluidity and red cell cytosolic $\mathrm{Ca}^{2+}$ content during incubation, in normals and in subjects with vascular atherosclerotic disease

619 Effect of suspending medium viscosity on orientation and deformation of RBCs in a shear flow field

627 Microcirculatory disorders in dermatomyositis: Plasma thrombomodulin changes as a marker of endothelial damage

633 Piyavit - a complex preparation from the medicinal leech improves blood rheology and decreases platelet aggregation

641 The effect of sod-active plant substance (Polbax $($ ) $)$ on oxygen free radical (OFR) generation and blood cell rheology

649 Dose-dependent hemorheological effects and microcirculatory modifications following intravenous administration of Ginkgo biloba special extract EGb 761

657 Platelet membrane fluidity and platelet cytosolic $\mathrm{Ca}^{2+}$ content in several clinical conditions 
E. Simon, S.M. Razavian, J. Le Beyec, V. Atger, J.-L. Paul, A. Simon, N. Moatti and J. Levenson

A. Vayá, M. Martínez, M.T. Santos, J. Vallés, I. Llopis and J. Aznar

H. Kiesewetter, A. Birk,

$\mathrm{N}$. Thme and F. Jung

F. Torregiani, M. Umansky-Zeverin,

B. Riquelme and R. Rasia

D.W. Lubbers
667 Influence of lipoprotein subfractions on dextran- and fibrinogen-induced erythrocyte aggregation

\section{Brief Communications}

677 Lipid peroxides and red blood cell deformability in familiar hypercholesterolemia

681 Association between vasoactive substances and the incidence of cardiovascular events

Letter to the Editors-in-Chief

687 Hemorheologic alterations in diabetic patients

\section{Book Review}

691 Microcirculation of the Brain, a Synoptic View by by World Experts

\section{Announcement}

693 4th International Conference on Physiogical Fluid Dynamics December 8-10, 1995, Jiwaji University, Gwalior, India

695 Contents of Biorheology Volume 32, Numbers 2-3 